\title{
Pengaruh Probiotik pada Diare Akut: penelitian dengan 3 preparat probiotik
}

\author{
Ken Shinta, ${ }^{*}$ Hartantyo, * Noor Wijayahadi** \\ **Bagian Pediatri Fakultas Kedokteran Universitas Diponegoro/RSUP Dr. Kariadi, Semarang \\ ***Bagian Farmakologi Fakultas Kedokteran Universitas Diponegoro/RSUP Dr. Kariadi, Semarang
}

Latar belakang. Probiotik diketahui memiliki dampak yang menguntungkan dalam pengobatan diare akut pada anak. Probiotik mengurangi frekuensi dan durasi diare dengan meningkatkan respon imun, produksi substansi antimikroba dan menghambat pertumbuhan kuman patogen penyebab diare. Probiotik dengan galur spesifik efektif menurunkan frekuensi dan durasi diare.

Tujuan. Membuktikan efektifitas suplementasi probiotik tunggal maupun kombinasi pada anak dengan diare akut.

Metode. Uji klinis acak tersamar buta ganda terhadap pasien diare akut usia 6-24 bulan dengan diare akut di RS Dr. Kariadi Semarang periode Juli 2010 - Februari 2011. Subyek dibagi dalam 3 kelompok perlakuan (kelompok 1 perlakuan L.reuteri, kelompok 2 perlakuan L.acidophilus-LGG, kelompok 3 perlakuan L.acidophilus-Blongum-S.faecium) dan kelompok 4 dengan plasebo. Probiotik diberikan selama 5 hari dalam bentuk bubuk. Setiap kelompok mendapat terapi standar berupa rehidrasi dan dietetik. Diamati rekuensi dan durasi diare perhari. Uji statistik dengan menggunakan One Way Anova.

Hasil. Dari 84 anak yang ikut dalam penelitian, rerata durasi diare lebih pendek pada kelompok L.reuteri $(37,4 \pm 14,4)$ jam dan L.acidophilus-LGG $(38,6 \pm 19,6)$ jam dibanding kelompok 3 galur probiotik dan kontrol ( $\mathrm{p}=0,002)$. Rerata frekuensi diare menurun pada kelompok L.reuteri $(5,6 \pm 2,9$ kali dan L.acidophilus-LGG $(6,9 \pm 8,4)$ kali dibanding dengan kelompok 3 galur probiotik dan kontrol $(p=0,02)$.

Kesimpulan. Probiotik $L$. reuteri dan L.acidophilus- $L G G$ efektif menurunkan durasi dan frekuensi diare. Probiotik dapat digunakan sebagai terapi tambahan pada anak dengan diare akut.

Sari Pediatri 2011;13(2):89-95.

Kata kunci: probiotik, diare akut, durasi, frekuensi.

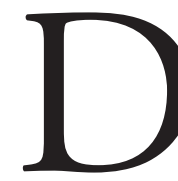

iare akut merupakan penyebab utama kematian dan malnutrisi pada anak, terutama di negara berkembang. Angka mortalitas diare menurun setelah WHO

\footnotetext{
Alamat korespondensi:

Dr. Ken Shinta. Bagian Pediatri RSUP Dr. Kariadi/Fakultas Kedokteran Universitas Diponegoro Jl. Dr Sutomo no 16 Semarang.

E-mail: Kenshinta@yahoo.com
}

pada tahun 1978 memperkenalkan terapi rehidrasi oral dengan larutan oralit, dari 4,5 juta (1979) menjadi 1,6 juta (2002) kematian per tahun. Di Indonesia diperkirakan terdapat 200-400 kejadian diare per 1000 penduduk dan penyebab kematian balita kedua setelah infeksi saluran pernafasan akut dengan 300.000500.000 kematian per tahun. ${ }^{1,2}$

Faktor-faktor yang mempengaruhi kejadian diare antara lain usia, asupan diet, status gizi dan keadaan 
mukosa usus. ${ }^{3}$ Usia kurang dari 2 bulan, asupan diet, pemberian ASI atau gizi yang buruk dapat mempengaruhi frekuensi dan durasi diare. Terapi baku pada diare akut sesuai pedoman WHO adalah pemberian cairan rehidrasi (oral dan parenteral), pemberian seng selama 10-14 hari serta meneruskan pemberian dietetik. ${ }^{1}$

Organisasi pangan dunia FAO dan WHO mendefinisikan probiotik sebagai mikroorganisme hidup yang bila dikonsumsi dalam jumlah yang adekuat sebagai bagian dari makanan akan memberikan dampak menguntungkan pada kesehatan pejamu. ${ }^{4}$ Mekanisme kerja probiotik adalah berkompetisi untuk berlekatan pada enterosit usus, sehingga enterosit yang telah jenuh dengan probiotik tidak dapat lagi berlekatan dengan bakteri lain sehingga menghambat pertumbuhan kuman patogen selain berkompetisi dengan patogen untuk mendapatkan tempat dan nutrisi. ${ }^{5}$ Probiotik juga menghasilkan substansi anti mikroba seperti asam organik (laktat dan asetat), bakteriosin, reuterin, $\mathrm{H} 2 \mathrm{O} 2$ dan enzim saluran cerna. ${ }^{6-8}$ Pengaruh probiotik terhadap sistem imunitas non spesifik adalah meningkatkan produksi musin, aktivitas sel natural killer (NK), aktivasi makrofag dan fagositosis. Probiotik juga mempengaruhi imunitas spesifik dengan meningkatkan produksi sitokin, seperti IL-2, IL-6, TNF- $\alpha$, dan kadar sIgA.7,

Probiotik yang efektif pada diare akut merupakan dependen galur (strain) dan dependen dosis. Galur yang terbukti efektif yang telah diteliti antara lain L.reuteri, L.acidophilus, L.rhamnosus $G G$ (LGG) dan B.lactis. Probiotik tunggal yang efektif pada diare akut antara lain L.reuteri dan $L G G{ }^{7,8,10,11}$ Kombinasi probiotik yang terbukti efektif antara lain L.acidophilus-B.bifidum dan L.acidophilus-S.thermophilus-B.bifidum-L.bulgaris. Sedangkan dosis yang efektif pada diare akut adalah $>10^{10} \mathrm{cfu} /$ hari dan sangat efektif jika diberikan pada awal terjadinya diare $(<48$ jam $)$, dengan rerata lama pemberian probiotik 5 hari. ${ }^{12,13,14}$

L.reuteri sebagai preparat tunggal efektif menurunkan frekuensi dan durasi diare dengan stimulasi imunitas dengan produksi asam organik (laktat dan asetat) dan reuterin serta meningkatkan kadar IL-2 dan TNF- $\alpha$. Reuterin menyebabkan kadar urease pada feses rendah sehingga dapat menekan pertumbuhan bakteri dan menghambat pertumbuhan kuman patogen pada saluran cerna. ${ }^{8}$ Efektivitas $L G G$ dan L.acidophilus sebagai preparat kombinasi masih terbatas, namun keduanya diketahui dapat memodulasi sistem imunitas dengan produksi asam laktat, $\mathrm{H} 2 \mathrm{O} 2$, laktase dan bakteriosin, meningkatkan aktivitas sel natural killer (NK), fagositosis oleh leukosit PMN dan makrofag serta meningkatkan kadar kadar IL-2, IL-6, TNF- $\alpha$, IFN- $\gamma$ dan sIgA. ${ }^{7,9}$ Bacillus.longum selain produksi asam organik dan $\mathrm{H} 2 \mathrm{O} 2$ diketahui meningkatkan kadar sIgA. ${ }^{15}$ Probiotik tersebut terbukti bermakna pada pencegahan diare akibat rotavirus dan diare terkait penggunaan antibiotik (antibiotic associated diarrheaAAD), namun efektivitasnya pada pengobatan diare akut belum banyak diteliti. Sedangkan S.faecium memodulasi sistem imunitas dengan memproduksi bakteriosin. Efektivitas S.faecium pada diare akut juga terbatas, sebagai preparat kombinasi S.faecium efektif menurunkan durasi dan frekuensi diare sebagai pada pencegahan diare akibat AAD. ${ }^{7}$ Diharapkan dengan dampaknya terhadap sistem imunitas, probiotik dapat dijadikan referensi sebagai terapi tambahan yang efektif pada diare akut, mengurangi beban ekonomi dengan menurunkan frekuensi dan durasi diare, sehingga menurunkan lama rawat inap di rumah sakit.

Penelitian bertujuan untuk mengetahui perbedaan frekuensi dan durasi diare setelah pemberian tiga preparat probiotik (L.reuterii, L.acidophilus-LGG, L.acidophilus-B.longum-S.faecium) pada anak dengan diare akut.

\section{Metode}

Desain penelitian adalah uji klinis tersamar buta ganda, subjek anak usia 6-24 bulan dengan diare cair akut yang dirawat di ruang perawatan Gastroenterologi Anak RSUP Dr. Kariadi Semarang pada periode Juli 2010 - Februari 2011.

Subjek penelitian harus memenuhi kriteria diare cair akut dengan lama $<7$ hari. Anak tidak diikutkan dalam penelitian jika menderita kelainan kongenital saluran cerna, gizi buruk (klinis dan antropometri), penyakit penyerta yang berat, dan dalam keadaan immunocompromised. Dinyatakan drop out jika selama pengamatan anak mengalami penyakit penyerta atau komplikasi yang berat. Dilakukan randominasi sederhana pada subjek yang turut dalam penelitian, kemudian dikelompokkan menjadi empat. Kelompok pertama (Probiotik 1) mendapat perlakuan berupa pemberian suplementasi L.reuteri, kelompok kedua (Probiotik 2) mendapat perlakuan berupa pemberian suplementasi LGG-L.acidophilus, kelompok ketiga (Probiotik 3) 
mendapat perlakuan berupa pemberian suplementasi L.acidophilus-B.longum-S.faecium, kelompok keempat sebagai kontrol mendapat plasebo.

Besar sampel dihitung dengan rumus uji hipotesis terhadap beda rerata, tingkat kemaknaan $\alpha 5 \%$ dan power $90 \%$. Setelah perhitungan dengan koreksi drop out, didapatkan besar sampel minimal 21 anak tiap kelompok.

Informed consent dilakukan kepada orang tua/ wali. Selanjutnya dilakukan anamnesis mengenai keluhan, durasi diare, frekuensi diare dan terapi sebelum dirawat inap, penilaian status hidrasi dan pemeriksaan antropometri untuk menentukan status gizi serta pemeriksaan feses rutin. Saat pemeriksaan awal setiap kelompok mendapat terapi baku rehidrasi dan dietetik sesuai prosedur yang telah ditentukan. Diberikan probiotik bentuk bubuk, L.reuteri $10^{10}$ CFU, L.rhamnosus R001 1,9 × $10^{9}$ CFU-Lacidophillus R0052 0,1 x 109 CFU, L.acidophillus-B. longum-S. faecium $1 \times 10^{7} \mathrm{CFU}$ atau plasebo, diberikan dua kali sehari setelah makan, selama lima hari. Jika pasien dinilai telah sembuh dan diijinkan pulang sebelum lima hari, pemberian probiotik tetap dilanjutkan dengan dilakukan pemantauan pemberian probiotik di rumah. Selama perawatan setiap hari dinilai status hidrasi dan pemantauan frekuensi diare, durasi diare, dan konsistensi feses.

Variabel yang diteliti adalah frekuensi diare per hari, yaitu jumlah defekasi dalam satu hari dan durasi diare yaitu lama diare setelah perlakuan sampai konsistensi feses menjadi normal dan atau frekuensi kurang dari 3 kali dalam sehari. Variabel perancu adalah adalah usia, status gizi, dan terapi sebelum dirawat inap. Nilai p bermakna apabila $\mathrm{p}<0,05$ dengan $95 \%$ interval kepercayaan dan power $90 \%$. Analisis statistik menggunakan program komputerisasi. Penelitian telah mendapatkan persetujuan Komite Etik Penelitian Kesehatan Fakultas Kedokteran Univesitas Diponegoro/RSUP Dr. Kariadi Semarang.

\section{Hasil}

Jumlah subjek yang masuk dalam penelitian 84 anak. Jumlah subjek masing-masing kelompok sama yaitu 21 anak. Tidak didapatkan hubungan yang bermakna secara statistik antara jenis suplementasi probiotik dengan usia, jenis kelamin, status gizi, lama diare sebelum dirawat dan frekuensi diare sebelum perlakuan. Pemberian antibiotik sebelum dirawat inap tidak dapat dianalisis, karena obat dalam bentuk bubuk sehingga tidak diketahui isi atau kandungannya.

Tabel 1. Karakteristik subyek penelitian

\begin{tabular}{|c|c|c|c|c|c|}
\hline \multirow[b]{2}{*}{ Karakteristik } & \multicolumn{4}{|c|}{ Kelompok } & \multirow[b]{2}{*}{ Nilai $\mathrm{p}$} \\
\hline & $\begin{array}{c}\text { Kontrol } \\
n=21\end{array}$ & $\begin{array}{c}\text { Probiotik } 1 \\
n=21\end{array}$ & $\begin{array}{l}\text { Probiotik } 2 \\
n=21\end{array}$ & $\begin{array}{c}\text { Probiotik } 3 \\
N=21\end{array}$ & \\
\hline Jenis kelamin & & & & & $0,46^{* *}$ \\
\hline Laki-laki & 11 & 13 & 16 & 13 & \\
\hline Perempuan & 10 & 8 & 5 & 8 & \\
\hline Umur (bulan) & $12,9 \pm 4,6$ & $11,9 \pm 5,2$ & $9,9 \pm 4,5$ & $9,8 \pm 3,9$ & $0,83 *$ \\
\hline Berat badan (kg) & $8,6 \pm 2,1$ & $7,9 \pm 1,5$ & $7,8 \pm 1,3$ & $7,9 \pm 1,5$ & $0,41 *$ \\
\hline Status gizi & & & & & $0,29^{* *}$ \\
\hline Gizi baik & 15 & 17 & 19 & 19 & \\
\hline Gizi kurang & 6 & 4 & 2 & 2 & \\
\hline \multicolumn{6}{|l|}{ Antibiotik sebelum dirawat } \\
\hline Ya & 7 & 4 & 3 & 4 & \\
\hline Tidak & 2 & 2 & 3 & 2 & \\
\hline Tidak tahu & 12 & 15 & 15 & 15 & \\
\hline Antibiotik saat rawat inap & & & & & $0,53^{* *}$ \\
\hline Ya & 3 & 7 & 6 & 6 & \\
\hline Tidak & 18 & 14 & 15 & 15 & \\
\hline Lama sakit sebelum dirawat (jam) & $86,3 \pm 31,7$ & $66,0 \pm 20,5$ & $78,2 \pm 34,9$ & $64,6 \pm 29,8$ & $0,06 *$ \\
\hline Frekuensi diare sebelum terapi (kali) & $22,1 \pm 10,7$ & $17,5 \pm 8,5$ & $23,1 \pm 14,3$ & $21,3 \pm 10,5$ & $0,31 *$ \\
\hline
\end{tabular}

* Uji Anova ** Uji Chi square 
Durasi diare menurun pada kelompok L.reuteri $(37,4 \pm 14,4)$ jam dan $L G G$-L.acidophilus $(38,6 \pm 19,6)$ jam dibandingkan kelompok kontrol. Didapatkan perbedaan yang bermakna secara statistik pada pemendekan rerata durasi diare antar kelompok penelitian $(\mathrm{p}=0,002)$. Terdapat penurunan rerata lama sakit antara ketiga kelompok probiotik dibanding dengan kelompok kontrol namun perbedaan tidak bermakna secara statistik $(\mathrm{p}=0,16)$.

Didapatkan perbedaan bermakna pada beda rerata durasi diare antara kelompok L.reuteri dengan L.acidophilus-B.longum-S.faecium $(\mathrm{p}=0,001)$ dan kontrol $(p=0,026)$. Setelah pengobatan lima hari didapatkan perbedaan bermakna pada beda rerata durasi diare antara kelompok $L G G$-L.acidophilus dengan kelompok L.acidophilus-B.longum-S.faecium $(\mathrm{p}=0,002)$ dan kontrol $(\mathrm{p}=0,042)$.
Rerata frekuensi diare menurun pada kelompok L.reuteri $(5,6 \pm 2,9) \mathrm{kali} / \mathrm{hari}$ L.acidophilus $-L G G$ $(6,9 \pm 8,4)$ jam dibanding kelompok kontrol. Didapatkan perbedaan bermakna secara statistik pada frekuensi diare setelah perlakuan antar kelompok $(\mathrm{p}=0,01)$. Tidak didapatkan perbedaan pada lama rawat inap antar kelompok ( $\mathrm{p}=0,07)$.

Didapatkan perbedaan bermakna pada rerata frekuensi diare antara kelompok L.acidophillus-B. longum-S.faecium dengan kelompok L.reuteri $(\mathrm{p}=0,006)$ dan dengan kelompok L.acidophilus- $L G G(\mathrm{p}=0,026)$.

Frekuensi diare per hari menurun pada masingmasing kelompok dan penurunan paling baik pada kelompok probiotik 1 dan probiotik 2. Didapatkan perbedaan bermakna pada beda frekuensi diare perhari pada hari kedua $(\mathrm{p}=0,03)$ dan hari ketiga antar kelompok $(\mathrm{p}=0,02)$.

Tabel 2. Perbedaan rerata durasi diare dan lama sakit antar kelompok

\begin{tabular}{|c|c|c|c|c|c|}
\hline \multirow[b]{2}{*}{ Parameter } & \multicolumn{4}{|c|}{ Kelompok } & \multirow[b]{2}{*}{ Nilai $\mathrm{p}$} \\
\hline & Kontrol & Probiotik 1 & Probiotik 2 & Probiotik 3 & \\
\hline Rerata durasi diare (jam) & $51,8 \pm 24,3$ & $37,4 \pm 14,4$ & $38,6 \pm 19,6$ & $58,9 \pm 22,7$ & $0,002 *$ \\
\hline Rerata lama sakit (jam) & $138,1 \pm 40,7$ & $103,5 \pm 22,9$ & $117,2 \pm 36,8$ & $123,4 \pm 34,6$ & $0,16^{*}$ \\
\hline
\end{tabular}

* Uji Anova

Tabel 3. Perbedaan rerata durasi diare antar masing-masing kelompok

\begin{tabular}{lcccc}
\hline Jenis Probiotik & Kontrol & Probiotik 1 & Probiotik 2 & Probiotik 3 \\
\hline Kontrol & & $0,026^{*}$ & $0,042^{*}$ & 0,27 \\
Probiotik 1 & $0,026^{*}$ & & 0,84 & $0,001^{*}$ \\
Probiotik 2 & $0,042^{*}$ & 0,84 & & $0,002^{*}$ \\
Probiotik 3 & 0,27 & $0,001^{*}$ & $0,002^{*}$ & \\
\hline
\end{tabular}

${ }^{*}$ Uji independen $\mathrm{t}$ test

Tabel 4. Perbedaan rerata frekuensi diare dan lama rawat inap antar kelompok

\begin{tabular}{lccccc}
\hline & \multicolumn{4}{c}{ Kelompok } & \multirow{2}{*}{ Nilai p } \\
\cline { 2 - 5 } Parameter & Kontrol & Probiotik 1 & Probiotik 2 & Probiotik 3 & \\
\hline Frekuensi diare (kali) & $11,3 \pm 12,1$ & $5,6 \pm 2,9$ & $6,9 \pm 8,4$ & $13,5 \pm 11,9$ & $0,01 *$ \\
Lama rawat inap (hari) & $5,2 \pm 2,4$ & $3,9 \pm 1,3$ & $4,2 \pm 1,0$ & $5,0 \pm 1,8$ & $0,07^{*}$ \\
\hline
\end{tabular}

* Uji Anova

Tabel 5. Perbedaan rerata frekuensi diare antar masing-masing kelompok

\begin{tabular}{lcccc}
\hline Jenis Probiotik & Kontrol & Probiotik 1 & Probiotik 2 & Probiotik 3 \\
\hline Kontrol & & 0,05 & 0,17 & 0,37 \\
Probiotik 1 & 0,05 & & 0,58 & $0,006^{*}$ \\
Probiotik 2 & 0,17 & 0,58 & & $0,026^{*}$ \\
Probiotik 3 & 0,37 & $0,006^{*}$ & $0,026^{*}$ & \\
\hline
\end{tabular}

* Uji independen $t$ test 
Ken Shinta dkk: Pengaruh probiotik pada diare akut

Tabel 6. Frekuensi diare per hari antar kelompok

\begin{tabular}{lccccc}
\hline Frekuensi harian & Kontrol & Probiotik 1 & Probiotik 2 & Probiotik 3 & Nilai p \\
\hline Hari pertama & $5,2 \pm 4,6$ & $3,5 \pm 2,6$ & $4,3 \pm 5,0$ & $7 \pm 5,9$ & $0,10^{*}$ \\
Hari kedua & $2,9 \pm 3,0$ & $1,6 \pm 0,8$ & $2,2 \pm 2,6$ & $4,2 \pm 3,9$ & $0,03^{*}$ \\
Hari ketiga & $2,0 \pm 4,1$ & $0,3 \pm 0,8$ & $0,5 \pm 0,9$ & $2,8 \pm 3,9$ & $0,02^{*}$ \\
Hari keempat & $1,0 \pm 2,8$ & $0,04 \pm 0,2$ & $0,04 \pm 0,2$ & $0,8 \pm 1,3$ & $0,08^{*}$ \\
Hari kelima & $0,04 \pm 0,2$ & 0 & 0 & 0 & $0,39^{*}$ \\
\hline
\end{tabular}

* Uji Anova

\section{Pembahasan}

Faktor-faktor yang mempengaruhi diare seperti usia, status gizi dan pemberian antibiotik saat dirawat inap tidak bermakna mempengaruhi diare. Tidak adanya perbedaan bermakna pemberian antibiotik saat dirawat antar kelompok penelitian mungkin disebabkan jenis, dosis dan lama pemberian yang tidak sama antar subjek penelitian (Tabel 1).

Durasi diare terpendek pada kelompok L.reuteri diikuti kelompok L.acidophilus-LGG. Antara kelompok dengan durasi diare terpendek, L.reuteri dan kelompok kontrol penurunan durasi diare adalah 14,4 jam. Hal ini sesuai dengan penelitian Shornikova $\mathrm{dkk}^{8}$ pada anak diare akut usia 6-36 bulan yang mendapatkan L.reuteri selama 5 hari, durasi diare menurun 40 jam dibanding dengan kontrol 69 jam (penurunan durasi 29 jam). Pada penelitian Shornikova tersebut 75\% penyebab diare adalah infeksi rotavirus. Efektivitas L.reuteri disebabkan oleh peningkatan kadar IL-2 dan TNF- $\alpha$ dan aktivitas antimikroba yang dihasilkannya, seperti asam laktat, asam asetat dan reuterin. Reuterin menyebabkan kadar urease pada feses rendah sehingga dapat menekan pertumbuhan bakteri dan menghambat pertumbuhan kuman patogen pada saluran cerna.

Probiotik kombinasi dan L.acidophilus- $L G G$ efektif menurunkan durasi diare (38,6 jam). Laporan penelitian mengenai efektivitas L.acidophilus sebagai preparat tunggal terbatas. Penelitian Guandalini dkk ${ }^{16}$ pada anak diare usia 1-36 bulan, pemberian preparat tunggal $L G G$ menurunkan durasi dibandingkan kontrol (58 dan 72 jam). Khanna dkk ${ }^{17}$ meneliti anak usia 6 bulan-12 tahun yang diberikan heat killed L.acidophilus, tidak didapatkan perbedaan yang bermakna dibanding dengan kontrol $(54,4$ dan 55,1 jam). Karakteristik subjek penelitian sangat berbeda dengan penelitian Khanna $\mathrm{dkk}^{17}$ yang menggunakan live probiotic. Penelitian Simakachron $\mathrm{dkk}^{8}$ menunjukkan kombinasi L.acidophilus-B.infantis menurunkan durasi diare dibanding kontrol $(3,1$ dan 3,6 hari), sedangkan penelitian Kianifar $\mathrm{dkk}^{12}$ menunjukkan kombinasi L.acidophilus-B.bifidum menurunkan durasi diare dibanding kontrol (3,4 dan 4,5 hari). ${ }^{18}$ Meskipun belum ada laporan penelitian sebelumnya mengenai kombinasi L.acidophilus- $L G G$, sebagai prerapat tunggal masing-masing galur terbukti efektif menurunkan durasi diare. Hasil yang bermakna pada penelitian kami, menunjukkan dampak sinergis dari kedua probiotik. Hal tersebut dapat disebabkan karena keduanya mempengaruhi imunitas non spesifik dan spesifik dengan menghasilkan asam organik, $\mathrm{H} 2 \mathrm{O} 2$, bakteriosin, meningkatkan aktivitas fagositosis dan sel NK, produksi sitokin IL2, IL-6, TNF- , IFN- , dan $\operatorname{sgA} .^{7,9}$

Pemberian probiotik kombinasi dengan tiga galur yang berbeda (L.acidophilus- B.longum-S.faecium) durasi dan frekuensi diare lebih panjang dibanding dengan kontrol. Penelitian Putra dkk ${ }^{19}$ pada anak usia 1-12 bulan menunjukkan probiotik dengan kombinasi galur yang sama dengan penelitian kami menurunkan durasi diare dibanding dengan kontrol (49,03 dan 73,03 jam). Selisih perbedaan durasi diare pada penelitian kami dan Putra dkk $^{19}$ sebesar 11,63 jam. Hasil penelitian dapat berbeda karena karakteristik penelitian berbeda dan pengaruh dari pemberian ASI eksklusif dapat mempengaruhi durasi diare. Juga berbeda dengan Canani $\mathrm{dkk}^{13}$ yang melakukan penelitian kombinasi L.bulgaricus-L.acidophilus-B. bifidum-S. thermophilus telah menurunkan durasi diare dibanding kontrol (70 dan 115,5 jam). Perbedaan tersebut disebabkan perbedaan karakteristik subjek, yaitu pasien rawat jalan berusia di atas 12 bulan dan mengeksklusi pemberian antibiotik sebelum terapi. ${ }^{19}$

Penelitian mengenai preparat tunggal S.faecium atau B.longum dan preparat kombinasi S.faecium pada diare akut anak sangat terbatas. Canani $\mathrm{dkk}^{13}$ melaporkan tidak didapatkan perbedaan durasi diare S.faecium dibanding kontrol (115 dan 115,5 jam). Pada dewasa yang mengalami diare dengan penyebab enterotoksigenik E.coli dan $V$. cholera, pemberian 
S.faecium tidak efektif menurunkan durasi diare. Hasil yang tidak bermakna pada penelitian kami mungkin disebabkan pemilihan galur probiotik yang tidak spesifik untuk diare akut sehingga tidak menimbulkan dampak sinergis, atau dapat juga disebabkan tidak adanya pengaruh B.longum dan S.faecium terhadap aktivitas fagositosis dan sedikit pengaruh keduanya terhadap imunitas spesifik. Probiotik B.longum meningkatkan kadar IgA sedang S.faecium tidak mempengaruhi imunitas spesifik. ${ }^{7,15}$

Frekuensi diare setelah perlakuan paling rendah pada kelompok L.reuteri (5,6 kali), diikuti L.acidophilusLGG (6,9 kali) dan perbedaan frekuensi diare antar kelompok bermakna secara statistik. Tidak didapatkan perbedaan yang bermakna pada frekuensi diare antara kedua kelompok. Penurunan frekuensi diare per hari didapatkan paling baik pada kelompok L.reuteri, frekuensi diare turun pada hari kedua $(1,6 \pm 0,8$ kali/hari) dan hari ketiga terapi $(0,3 \pm 0,8 \mathrm{kali} / \mathrm{hari})$. Hasil yang sama juga didapatkan Shornikova dkk, ${ }^{8}$ yaitu rerata frekuensi diare kelompok probiotik menurun pada hari kedua (1 kali/ hari dan kelompok kontrol 2,5 kali/hari) dan hari ketiga (0,5 kali/hari dan kelompok kontrol 1,7 kali/hari).

Efektivitas probiotik pada diare akut anak mempunyai sifat strain specific. Dengan asumsi bahwa galur tertentu efektif pada diare akut, jika dikombinasi dengan galur lain dengan spesies yang sama akan tetap efektif selama tidak menimbulkan dampak antagonis, begitu pula jika diberikan sebagai kombinasi dengan genus yang berbeda. ${ }^{6}$ Penelitian untuk membandingkan masing-masing galur masih terbatas, efektivitas memodulasi sistem imun, dan kompetisi dengan kuman patogen juga belum banyak diketahui. Dari penelitian sebelumnya hanya $L G G$ dan L.reuteri sebagai preparat tunggal yang terbukti efektif menurunkan durasi diare terutama dengan penyebab rotavirus. Pada penelitian kami L.reuteri sebagai preparat tunggal dan kombinasi L.acidophilus$L G G$ efektif menurunkan frekuensi dan durasi diare, meskipun tidak didapatkan perbedaan yang bermakna antar kedua kelompok. Keterbatasan penelitian ini adalah tidak mencari etiologi patogen penyebab diare dan tidak mengukur kadar IgA.

\section{Kesimpulan}

Probiotik L.reuteri dan kombinasi L.acidophilus- $L G G$ efektif menurunkan frekuensi dan durasi diare akut.
Pemberian suplementasi probiotik dapat dijadikan sebagai prosedur tetap pada pengelolaan diare akut anak untuk memperpendek durasi dan frekuensi diare. Perlu dilakukan penelitian lebih lanjut terhadap pengaruh suplementasi probiotik dengan galur yang spesifik terhadap durasi serta frekuensi diare, dan pengaruh suplementasi probiotik terhadap sistem imunitas dengan pengukuran kadar IgA.

\section{Daftar pustaka}

1. World Health Organization. Implementing the new recommendation on the clinical management of diarrhea: guidelines for policy makers and programme managers. Geneva: WHO Press 2006.

2. Modul Pelatihan tatalaksana diare pada anak. Jakarta: Badan Koordinasi Gastroenterologi Anak Indonesia 2007.

3. Sudigbia I. Pengantar diare akut anak. Semarang: BP UNDIP;1991.h.1-61.

4. World Gastroenterology Organisation Practice Guideline. Probiotics and prebiotics. 2008.

5. Sudarmo SM. Peran probiotik dan prebiotik dalam upaya pencegahan dan pengobatan diare pada anak. Dalam: Kumpulan makalah Kongres Nasional II Badan Koordinasi Gastroenterology Anak Indonesia (BKGAI). Bandung, 3-5 Juli 2003.

6. Ouwehand A, Lahtinen S. Mechanism of probiotics. Dalam: Lee YK, Salminen S, penyunting. Handbook of probiotik and prebiotik. Edisi ke-2. Wiley; 2009.h.377440.

7. Szajewska H. Probiotics and prebiotics in pediatrics: where are we now? Turkish J Pediatr 2007;49:231-44.

8. Shornikova AV, Casa IA, Isolauri E, Mykkanen H, Vesikari T. Lactobacillus reuteri as a therapeutic agent in acute diarrhea in children. J Paediatr Gastroenterol Nutr1997;24:399-404.

9. Gill HS, Rutherfurd KJ, Prasad J, Gopal PK. Enhancement of natural and acquired immunity by Lactobacillus rhamnosus, Lactobacillus acidophilus and Bifidobacterium lactis. Brit J Nutr 2000;83:167-76.

10. Saavedra JM. Use of probiotic in pediatrics: rationale, mechanisms of action, and practical aspects. Nutr Clin Prac 2007;22:351-65

11. FAO/WHO. Health and nutritional properties of probiotics in food including powder milk with live lactic acid bacteria. FAO/WHO. Argentina, 2001.

12. Kianifar HR, Farid R, Ahanchian H, Jabbari F, Moghiman T, Sistanian A. Probiotic in the treatment 
of acute diarrhea in young children. Iran J Med Sci 2009;34:204-7.

13. Canani RB, Cirillo P, Terrin G, Cesarano L, Spagnuolo MI, De Vincenzo A, dkk. Probiotics for treatment of acute diarrhea in children: randomized clinical trial of five different preparations. Diunduh dari: URL: http:// bmj.com/cgi/content/full/bmj.39272.581736.55. Pada 14 Januari 2009.

14. Niel CWV, Feudtner C, Garrison MM, Christakis DA. Lactobacillus therapy for acute infectious diarrhea in children: a meta-analysis. Pediatrics 2002 : 678-84

15. Miettinen M, Varkila JV, Varkila K. Production of human tumor necrosis factor alpha, interleukin-6 and interleukin 10 is induced by lactic acid bacteria. Infection and immunity. 1996; 64:5403-05.
16. Guandalini S. Recommendations for probiotic use. J Clin Gastroenterol 2008:42; S53-7.

17. Khanna V, Alam S, Malik A. Efficacy of tyndallized Lactobacillus acidophilus in acute diarrhea. Indian J Pediatr 2005;72:935-8.

18. Simackachron N, Pichaipat V, Rithipompaisam P, Kongkaew C, Tongpradit P, Varavithya W, dkk. Clinical evaluation of addition lypholized, heat killed lactobacillus acidophilus LB to oral rehydration therapy in treatment of acute diarrhea in children. J Paediatr Gastroenterol Nutr 2000;30:68-72.

19. Putra IGNS, Suraatmaja S, Aryasa IKN. Effect of probiotics supplementation on acute diarrhea in infants: a randomized double blind clinical trial. Paediatr Indones July 2007;52:172-8. 